\title{
LOCALIZATION ECONOMIES, VERTICAL ORGANIZATION, AND TRADE
}

Gordon H. Hanson

Working Paper No. 4744

\section{NATIONAL BUREAU OF ECONOMIC RESEARCH 1050 Massachusetts Avenue \\ Cambridge, MA 02138 \\ May 1994}

I thank Michael Conroy, Dan Hamermesh, Paul Krugman, Preston McAfee, and Michael Piore for helpful comments. Financial support from the MacArthur Foundation is gratefully acknowledged. This paper is part of NBER's research program in International Trade and Investment. Any opinions expressed are those of the author and not those of the National Bureau of Economic Research. 


\title{
LOCALIZATION ECONOMIES, VERTICAL ORGANIZATION, AND TRADE
}

\begin{abstract}
This paper develops a model of regional production networks based on localization economies. I consider an industry with two activities: one with location-specific external economies, the other with constant returns. Under autarky, localization economies imply the formation of an industry center. Agglomeration drives up wages in the center, causing the constant returns activity to disperse to outlying regions. Trade recreates the regional production network on a global scale. I apply the model to data from the Mexican apparel industry. Estimation results on Mexico's pre- and post-trade regional apparel wage structure are consistent with localization economies. Implications for the North American Free Trade Agreement (NAFTA) are discussed.
\end{abstract}

\section{Gordon H. Hanson}

Department of Economics

University of Texas

Austin, TX 78712

and NBER 


\section{Introduction}

The past decade has witnessed an unprecedented move towards free trade in the developing world. As expected, trade has led to a sectoral reallocation of resources towards labor-intensive activities (Michaely, Papageorgious, and Choksi 1991). Somewhat less expected, trade has also led to a vertical reorganization of production: labor-intensive industries, such as apparel, footwear, and electronics, are shifting from vertically-integrated production for the domestic market to the specialized task of product assembly for foreign firms (Grunwald and Flamm 1985). In this arrangement, which I term a regional production network, developedcountry firms supply product designs, process technology, and marketing services and subcontract assembly services to branch plants in developing countries. Regional production networks account for a large portion of developing-country trade. In Mexico, for instance, assembly plants accounted for 40 percent of 1992 total exports and 53 percent of 1992 manufacturing exports.

In this paper, I develop a model of regional production networks and apply it to a study of the Mexican apparel industry. The distinguishing feature of an regional production network is that the services developed-country firms provide - design, engineering, and marketing - are skill-intensive. The model is based on the idea there are external economies in these activities which account for the observed pattern of industry location. Consider a small country (where size proxies for development) with an industry that has two production stages: design, which has location-specific external economies, and assembly, which has constant returns to scale. Localization economies arise endogenously from the fact design involves many specialized subsidiary services, each produced under increasing returns to scale. By agglomerating in an industry center, firms share design capacity and expand the range of services available to them. 
Agglomeration, however, drives up wages in the industry center, pushing assembly into outlying regions. Now suppose the small country opens to trade with a large country. Trade recreates the regional production network on a global scale: the large country, by virtue of its size, captures the industry center, the small country, given low relative wages, specializes in assembly.

The model extends the vertical-production framework in Rivera-Batiz (1988) and Krugman and Venables (1993) to one in which labor is mobile regionally and internationally. Regional production networks resemble multinational enterprises in that trade may take the form of intrafirm transactions (Helpman and Krugman 1985 and Markusen and Rutherford 1993). Regional production networks, however, are not restricted to intrafirm trade. Indeed, the semidurable good industries in which regional production networks predominate contain many firms and involve substantial interfirm trade. The tension between agglomeration and congestion costs draws on models of city formation due to increasing returns (Fujita 1988 and Krugman 1991).

Mexico provides a unique opportunity to study the effects of trade on industry location. In 1985, Mexico decided to join the General Agreement on Trade and Tariffs (GATT), bringing a sudden end to four decades of import-substitution industrialization. For Mexico, the proximity and size of the U.S. economy makes trade liberalization tantamount to economic integration with its northern neighbor. The recent passage of the North American Free Trade Agreement (NAFTA) only formalizes a de facto process of integration already under way.

What makes apparel an interesting case is the variation in resource intensity across production stages. Some activities, such as design and finishing, are specialized tasks that require skilled labor. In the global apparel industry, specialized input suppliers are agglomerated in a few locations, such as New York, Los Angeles, and Hong Kong. (The simple fact New York 
City remains a major apparel producer is perhaps the most persuasive evidence one can find of localization economies.) Assembly, the other major production task, requires relatively few skills. Firms in global apparel centers subcontract assembly to firms in low-wage regions.

The data are consistent with the hypothesis of localization economies. Under the closed economy, high-skill apparel tasks clustered in Mexico City, while assembly took place in outlying regions. With the opening to trade, Mexican apparel producers are shifting from production for the domestic market to product assembly for U.S. firms. Econometric estimation of Mexico's pre and post-trade regional wage structure supports the theoretical results. This suggests NAFTA will not only shift apparel assembly jobs from the United States to Mexico, as many studies have predicted, but also lead to a substantial relocation of production within Mexico, reducing wages in Mexico City relative to those along the Mexico-U.S. border.

The body of the paper contains three sections. Section two develops a model of a regional production network. Section three presents data on the location and organization of the Mexican apparel industry. Section four presents empirical results. A final section concludes.

\section{Theory}

\section{A. The Model}

Consider two countries, Foreign, which has a single region and represents the United States, and Home, which has two regions, North and South, and represents Mexico. Each country has landowners, who own one unit of land, and workers, who own one unit of labor. Foreign has $L^{\circ}$ workers and $X^{\bullet}$ landlords; Home has $L$ workers and $X$ landlords. I assume $L^{*} \geq L$ and $X^{*}$ $2 X$. Labor is mobile across regions and may be mobile across countries; land is completely 
immobile. Endowments are supplied inelastically; landowners receive rental income and workers receive wage income. Tastes and technology are identical in each country. There are two consumption goods, housing, $X$, and apparel, $Y$. Each country spends a share $\alpha$ of its income on housing and a share $1-\alpha$ on apparel, as would arise with identical Cobb-Douglas preferences.

I use apparel production to motivate the model, but the basic technology -- a production process that has both specialized high-skill tasks and routine low-skill tasks -- is general to many semi-durable consumer goods. High-skill activities occur in the initial and final stages of apparel production. Before making a garment, a firm must create a design and turn the design into a workable pattern. The finishing stage includes detail activities such as pleating, belomaking, and embroidering. I capture skill intensity by assuming design and finishing services have increasing returns to scale. The intermediate stage of apparel production is product assembly, in which workers sew together cut pieces of fabric. Unlike design and finishing, assembly is a basic activity that requires few skills. It accounts for three-fourths of apparel employment.

Production of apparel, $Y$, is given by

(1) $Y=z^{1-0}$

$Z$ is an intermediate input that represents assembly, for which production is given by

(2) $z=L$,

where $L_{2}$ is labor used in $Z . V$ is an aggregate of many differentiated producer services,

(3) $V=\left(\sum_{i=1}^{\infty} s_{1}\right)^{\frac{2}{6}} \quad 0<0<1$

$S_{i}$ is output of service $i, N$ is the number of services provided (both of which are endogenous), 
and $\sigma$ measures the substitutability of services in production (as $\sigma$ goes to 1 services become perfect substitutes). Each service is produced under an identical increasing-returns technology

$$
\text { (4) } L_{1}=a+b s_{1}
$$

where $L_{1}$ is labor used in producing service $S_{i}$. The symmetry of producer services implies

$$
\text { (5) } 3-\sum_{1=1}^{\pi} s_{1}=N s_{1}
$$

which, following Rivera-Batiz (1988), allows me to rewrite (1) as

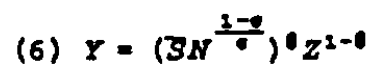

Equation (6) shows the source of external economies: output of $Y$ is increasing in $N$. As more services become available, the production process becomes smoother and final-good output increases, holding constant total service output.

A crucial assumption is that $Z$ is traded actoss regions but services are not. What makes services non-traded is that relative to transport costs the value added of an individual service is small. The same is not true for assembly, which makes it feasible to subcontract the activity to distant locations. To produce $Y$ a firm needs to be in a region where $S$ production occurs. With increasing returns, not all services can be produced. The arrival of an additional $Y$ producer expands the range of services provided, conferring an externality on firms already in the region.

\section{B. Autarky}

Foreign. First consider autarky in Foreign. Suppose there are a large number of service firms, each producing a single product. Given the service aggregate (3), I can apply the standard result 
that the price-elasticity of demand facing any individual firm is $(1-\sigma)^{-1}$ (Helpman and Krugman 1985). The profit-maximizing behavior of a representative service firm is to price according to

$$
\text { (7) } P^{*}{ }_{11}=\frac{w^{*} b}{\sigma}
$$

where $P^{*}$ is the price of service $i$. With free entry into services, profits will be driven to zero, which implies

$$
\begin{aligned}
& \text { (8) } P^{\bullet}{ }_{a 1} S^{\circ}{ }_{1}=W^{\circ}\left(a+b S^{\circ}\right) \\
& \text { (9) } S^{\circ}{ }_{1}=\frac{a \sigma}{b(1-\sigma)} \\
& \text { (10) } L^{\cdot}{ }_{1}=\frac{a}{1-\sigma}
\end{aligned}
$$

Symmetry implies all service firms choose the same price and output levels.

Profit maximization in $Y$ production implies

$$
\begin{aligned}
& \text { (11) } \frac{M^{0}}{P_{y}^{0}}=(1-\theta) z^{-0}\left(\sum_{1}^{\pi} s_{1}^{0}\right)^{\frac{1}{0}}
\end{aligned}
$$

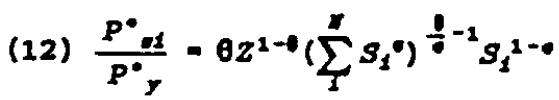

Combining (7), (9), (10), and the above first-order conditions yields

(13) $N^{*} \frac{a}{1-0} \frac{1-\theta}{\theta}=z$

Using (2) and the full-employment condition in Foreign, $L_{z}+N L_{i}=L^{\circ}$, I derive that

$$
\begin{aligned}
& \text { (14) } N^{*}-L \cdot \frac{\theta(1-\sigma)}{a} \\
& \text { (15) } L_{*}^{*}-L^{\bullet}(1-\theta)
\end{aligned}
$$

Due to increasing returns, $N$ is increasing in the labor supply. As $\sigma$ goes to 1 (services become more substitutable) $N$ becomes small. From (14) and (15) it is trivial to solve for relative prices. 
Home. Autarky in Home has three possible configurations of production: (i) regional autarky, (ii) agglomeration of $S$ and $Y$ in one region, with $Z$ divided between the regions, and (iii) regional specialization, in which one region specializes in $Z$ and the other in $S$ and $Y$. Depending on parameter values, either (i) and (ii) or (i) and (iii) are both equilibria. Regional autarky, however, is unlikely to be a stable equilibrium. Given external economies are localized, $Y$ producers want to be near $S$ producers and vice-versa. If one region gains a slight advantage in the number of service firms, it will attract all of the $Y$ producers. For this reason, I focus on agglomeration equilibria. Without loss of generality, I assume $S$ is produced in South and $Z$ is divided between the two regions and then derive the conditions consistent with this outcome.

To make distance matter, I assume there are transport costs between production stages. Think of these costs as resulting from coordinating production in different locations. Transport costs take an "iceberg" form: of each unit of $Z$ shipped between regions, a fraction $\delta<1$ arrives.

Service output in Home is the same as in Foreign, given in (9), and service prices are again a fixed markup over cost, as in (7). The number of services produced is not necessarily the same. Let $n$ denote North and $s$ denote South. Profit maximization implies

$$
\begin{aligned}
& \text { (16) } \frac{N^{*}}{P_{y}}=\frac{\sigma \theta}{b} Z^{1-0} N^{\frac{1}{\theta}-1} S_{I}^{0-1} \\
& \text { (17) } \frac{\mathscr{N}^{*}}{P_{y}}=(1-\theta) z^{-1} N^{\frac{1}{*}} S_{i}^{0} \\
& \text { (18) } \frac{w^{2}}{P_{y}}-(1-\theta) z^{-1} \frac{1}{2} S_{1}^{18}
\end{aligned}
$$

which implies that $N$ and $Z$ are related as in (13) and that

$$
\text { (19) } \frac{w^{a}}{w^{2}}=\frac{1}{\delta}>1
$$

Nominal wages are lower in North due to transport costs in delivering $Z$ to the industry center. 
Land rents work against agglomeration, ensuring production occurs in North. Assume the $X$ landowners are equally divided between North and South. Market clearing in $X$ implies

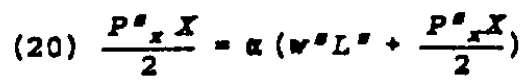

$$
\begin{aligned}
& \text { (21) } \frac{P^{n} x^{X}}{2}=\alpha\left(w^{2} L^{n}+\frac{P^{n} x^{X}}{2}\right)
\end{aligned}
$$

which yields the following condition:

$$
\text { (22) } \frac{W^{2} P^{n} x}{N^{4} P^{2}}=\frac{L^{n}}{L}
$$

Labor mobility requires that real wages are equalized across regions,

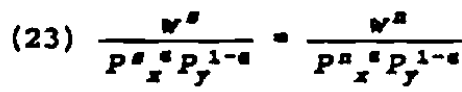

(24) $\frac{N^{*}}{W^{2}}=\left(\frac{p^{2} x}{p^{2}}\right)$

Combining (19), (22), (24), and the fact that $L^{\prime}+L^{n}=L$ yields

$$
\begin{aligned}
& \text { (25) } \frac{L}{L^{2}}-8^{\frac{E-1}{6}}>1 \\
& \text { (26) } L=-\frac{L}{1+8^{\frac{E-1}{6}}}, \quad L=\frac{L 8^{\frac{E-1}{6}}}{1+8^{\frac{c-1}{4}}}
\end{aligned}
$$

The formation of an industry center in South gives South a larger share of labor force than North. Using (13) and the fact that $L^{*}=L^{*},+N L_{i}, L^{n}=L^{n}$, and $Z=L^{*},+\delta L^{n}$, I derive

$$
\begin{aligned}
& \text { (27) } N=\frac{\theta(1-0)\left(8^{\frac{e-1}{a}}+8\right)}{a\left(1+8^{\frac{a-1}{6}}\right)} L \\
& \text { (28) } L=.=\frac{(1-0) 8^{\frac{a-1}{a}}-08}{1-8^{\frac{8-1}{a}}} L
\end{aligned}
$$


The condition that $Z$ production occurs in South, the industry center, is that $I-\theta>\theta \delta^{\prime \prime \alpha}$, which is more likely to hold the larger the $Z$ share in output and the higher transport costs.

Under autarky, the interaction of localization economies and transport costs creates a regional production network: high-skill activities concentrate in an industry center, low-skill activities disperse to low-wage regions. Agglomeration bids up the price of land in the center, driving workers into the non-agglomerated region. Positive transport costs counteract migratory pressures, as firms pay lower wages in regions distant from the industry center.

\section{Trade}

Consider trade between Home and Foreign where labor is immobile between countries. To retain regional symmetry in Home, I assume there are iceberg transport costs of $\gamma$ on each unit of $Z$ shipped from North or South to Foreign.

Given $L^{*}>L$, we expect Foreign to be the low-cost producer of $Y$. This will be the case if $w^{*} / P^{*}$, the Foreign relative price of $Z$ and $Y$, exceeds $w^{\prime} /\left(\gamma P P_{y}\right)$, the Home relative price of $Z$ and $Y$, which, applying the autarky equilibrium solutions to (11) and (17), requires

$$
\text { (29) } \frac{L^{*}}{L}>\frac{8^{\frac{a-1}{4}}+8}{8^{\frac{8-1}{6}}+1}
$$

A sufficient condition for (29) to hold is that Foreign has a larger labor force than Home.

Autarky relative prices do not uniquely determine the trading equilibrium. External economies imply one country will capture $Y$ production. Even if Foreign is the larger country, Home could become the industry center. If firms in both countries believe $S$ and $Y$ production will concentrate in Home, no individual Foreign firm will have an incentive to enter either 
industry. Autarky relative prices, however, are likely to be a strong guide. If in adjusting to trade firms respond to autarky relative prices, then in the equilibrium that obtains Home will specialize in $Z$ and Foreign will specialize in $S$ and $Y$. It is this equilibrium I study.

If Foreign captures the entire $Y$ market, all home labor is dedicated to $Z$ production and Foreign labor is divided between $S$ and $Z$. Since the output of each service is given by (10), the trading equilibrium can be summarized by solving for $L^{*}$, the amount of Foreign labor dedicated to $Z$ production, and $N^{\circ}$, the number of foreign service firms. Profit maximization implies

$$
\begin{aligned}
& \text { (30) } \frac{w^{*}}{P_{y}}=\frac{\sigma \theta}{b} z^{1-0} N^{\frac{1}{\sigma}-1} s_{1}^{0-1} \\
& \text { (31) } \frac{r^{*}}{P_{y}}=(1-\theta) z^{-0}{ }^{\frac{1}{\sigma}} s_{1}^{0} \\
& \text { (32) } \frac{w^{*}}{P_{y}}=(1-\theta) z^{-0} N^{\circ} s_{1}^{0} Y \\
& \text { (33) } \frac{w^{n}}{P_{y}}=(1-\theta) z^{-0}{ }^{\frac{1}{6}} s_{1}^{0} Y
\end{aligned}
$$

Trade recreates the regional production network on a global scale: Foreign becomes the global industry center and subcontracts input production to Home. Equations (32) and (33) show that $w^{\prime}=w^{\wedge}$, which implies $L^{\prime}=L^{\wedge}=L / 2$ or that trade causes a spatial redistribution of labor in Home. Home specialization in $Z$ means firms in South have no basis for paying high relative wages; regional wage equalization in Home causes migration from South to North. Let the Home wage be $w$. Equating (32) and (31), $w^{\circ} / w=1 / \gamma>1$. If $Z$ production occurs in both Home and Foreign, nominal wages are equalized in the two countries, adjusting for transpor costs.

The condition for factor-price equalization (FPE) is the same as that for $Z$ production to occur in Foreign. Equating (30) and (31) and using the fact that $L^{\circ}, N L_{i}=L^{*}$ 


$$
\begin{aligned}
& \text { (34) } N^{*}=\frac{\theta(1-\sigma)}{a}\left(L^{*}+Y L\right) \\
& \text { (35) } L^{*}=L^{\cdot}(1-\theta)-\theta \gamma L
\end{aligned}
$$

The condition for FPE, then, is that $L / L^{*}>(I-\theta) / \theta$, which is more likely to hold the smaller is Home relative to Foreign, the smaller is the share of $Z$ in $Y$ production, and the smaller are transport costs (i.e., the larger is $\gamma$.

Since the motivating example for the model is Mexico-U.S. trade, it may seem odd to focus on the FPE case. Wages in the United States clearly exceed those in Mexico. Some portion of the difference is surely due to productivity differences. If we think of $L$ and $L^{*}$ as efficiency units, FPE is the equalization of wages per efficiency unit. Still, massive Mexican immigration into the United States is evidence wages per efficiency unit are not equalized in the two countries. Appendix A considers the case where FPE does not obtain and there is migration from Home to Foreign. The results are qualitatively the same as those with immobile labor.

\section{The Data}

This section presents evidence on the organization and location of apparel production in Mexico before and after trade liberalization. I employ data from the Mexico Industrial Census and from 95 firm-level interviews I conducted in the Mexican apparel industry during 1990-1991 (appendix B describes interview methods and the sample of firms). Firm-level interviews are the only source of information on the internal organization of firms. Interview material suggest patterns of industrial organization that in most cases can be corroborated by Census data. ${ }^{1}$

\footnotetext{
1 Interview material are used solely to determine the nature of subcontracting activities. All data for estimation and summary statistics are from the Industrial Census or another cited source.
} 
The simple model presented above captures the essential features of apparel production and trade in Mexico. Under the closed economy, high-skill apparel tasks concentrated in Mexico City; low-skill tasks located in nearby communities. With the opening to trade, Mexico is shifting from vertically-integrated production for the domestic market to product assembly for foreign manufacturers. The shift involves industry relocation to the Mexico-U.S border region.

\section{A. Trade Policy in Mexico}

Mexico began to construct a trade regime based on import substitution in the 1940's. Trade restrictions took the form of import licenses, tariffs, and export controls (King 1970). In 1985, Mexico reversed its inward-oriented policy and began to liberalize trade. Between July 1985 and December 1987, import-license requirements fell from 92.2 percent of national production to 23.2 percent, and the production-weighted-average tariff fell from 27 percent to 11.0 percent, with a 20 percent maximum. In apparel, the weighted-average tariff fell from 49.8 percent to 20 percent and import licenses fell from 100.0 percent to zero (Hanson 1994).

Trade liberalization was not the apparel industry's first exposure to world markets. In the 1960 's, the government began to allow off-shore assembly in free-trade zones along the MexicoU.S. border (Grunwald and Flamm 1985). Off-shore assembly is one component of regional production networks. A foreign firm, typically from the United States, establishes an assembly plant, known as a maquiladora, in Mexico. The maquiladora imports all inputs from the foreign firm, assembles the inputs in Mexico, and exports the final product back to the foreign firm. ${ }^{2}$ Off-shore assembly plants are exempt from import duties as long as they export all output.

\footnotetext{
2 Item 807 of the U.S. tariff schedule allows firms that engage in off-shore assembly of U.S. manufactured components to only pay import duties on the value-added abroad.
} 
Figure 1 shows the value of imports and exports for domestic and off-shore apparel industries from 1982 to 1990 (Secretariat of Trade and Industrial Promotion, unpublished data). ${ }^{3}$ Trade has increased dramatically since liberalization. The United States is Mexico's major trading partmer in apparel. In 1990, 66.2 percent of non-maquiladora apparel exports went to the United States, and 52.9 percent of Mexican apparel imports came from the United States.

\section{B. The Vertical Organization of Apparel Production}

Apparel production is organized around assembly subcontracting. Manufacturers control product design, finishing, and marketing, and divide assembly between their own shops and independent subcontractors. Under the closed economy, most domestic apparel manufacturers located in Mexico City and subcontracted assembly to shops in nearby communities. The Mexico Industrial Census provides indirect evidence of subcontracting. Table 1 reports the size distribution of apparel establishments in 1980. At one end of the distribution are a small number of large establishments - the manufacturers; 250 shops, about 2 percent of establishments, with 100 or more workers accounted for 43.0 percent of total apparel employment. At the other end of the distribution are a large number of small establishments -- the subcontractors; 9,233 shops, about 75 percent of establishments, employed five or fewer workers.'

Domestic manufacturers were not the only source of assembly subcontracting in the closed economy. Through maquiladoras, foreign manufacturers also subcontracted assembly activities

Talue added in off-shore apparel exports is off-shore exports less imported inputs.

- Virtually all maquiladora exports 80 the United States. Mexico remains a small player in the U.S. market. In 1987, only 2.3 percent of U.S. imports of apparel and finished textile products (SIC 23) came from Mexico.

3 Establishments without paid labor include the self-employed and shops that hire only family labor. 
to Mexican firms. Despite the similarities in domestic and off-shore subcontracting, the two industries remain entirely separate. Apparel maquiladoras have virtually no linkages with domestic industry. Foreign firms provide all inputs, including fabric, and the maquiladoras, as the law stipulates, export virtually all of their output. ${ }^{6}$

Table 1: Size Distribution of Apparel Establishments, 1980

\begin{tabular}{|c|c|c|c|c|c|}
\hline \multirow{2}{*}{\multicolumn{2}{|c|}{ Establishment Type }} & \multicolumn{2}{|r|}{ Number of } & \multicolumn{2}{|c|}{ Share of Total } \\
\hline & & Estab. & Workers & Estab. & Workers \\
\hline Establishments $w / 0$ & Paid Labor & 7,047 & 10,515 & 0.578 & 0.073 \\
\hline Establishments w/ & Paid Labor & 5,152 & 133,831 & 0.422 & 0.927 \\
\hline Paid & 1 to 5 & 2,186 & 6,188 & 0.179 & 0.043 \\
\hline Workers & 6 to 25 & 1,842 & 22,468 & 0.151 & 0.156 \\
\hline per & 26 to 100 & 874 & 43,185 & 0.072 & 0.299 \\
\hline Estab. & $101+$ & 250 & 61,990 & 0.021 & 0.430 \\
\hline Total & & 12,199 & 144,346 & -- & -- \\
\hline
\end{tabular}

\section{The Geography of Production and Wages in the Closed Economy}

Figure 2 shows the location of apparel and overall manufacturing employment in Mexico from 1970 to 1988 (Censo Industrial, various years). In 1970, 55.4 percent of national apparel employment was located in the Federal District, the federal entity which contains Mexico City. In the 1970's manufacturers began to leave the capital; the share of apparel employment located in the Federal District declined to 33.2 percent in 1985. During the same period, the share of apparel jobs located in central states, which neighbor the capital, increased from 13.5 percent to

\footnotetext{
- Between 1981 and 1988, domestic inputs accounted for an average of 0.25 percent of inputs consumed by apparel maquiladoras on the Mexico-U.S. border (INEGI, 1989a).
} 
24.3 percent, and the share in north-central states increased from 12.5 percent to 21.6 percent. $^{7}$ Interview material suggest the activities that left the capital were those related to assembly, and that design, finishing, and marketing remained concentrated in Mexico City; in $1980,69.8$ percent of wholesale trade in apparel and textiles was still conducted in the Federal District.

The relocation of apparel production followed the emergence of wage differentials between Mexico City and outlying states. Figure 3 shows the ratio of average nominal regional wages to average nominal national wages in apparel and all manufacturing from 1970 to 1988 (Censo Industrial, various years).' In 1970, average apparel wages in the Federal District ranged from 1.11 times those in central states to 2.97 times those in southern states. Apparel jobs did not move to regions with the lowest relative wages, but to regions nearest the capital.

\section{Industrial Organization and Trade Liberalization}

Since the opening to trade in 1985, there has been a substantial relocation of Mexican apparel production. Figure 2 shows that between 1980 and 1988 the share of apparel employment in border states increased from 15.0 percent to 21.8 percent, while the share of apparel employment in the Federal District and Central states declined. There has also been a shift from domestic production towards off-shore apparel assembly. Table 2 shows total

- Central states adjoin the Federal District (Hidalgo, Mexico, Morelos, Puebla, Tlaxcala, Veracruz); NorthCentral states are non-border states north of the capital (Aguascalientes, Baja California Sur. Durango, Guanajuato, Jalisco, Nayarft, Queretero, San Luis Potosi, Sinaloa, Zacatecas); border states adjoin the US. (Baja California, Coahuila, Chihuahua, Nuevo Leon, Sonora. Tamaulipas); and South states are those south of the capital (Campeche, Colima, Chiapas, Guerrero, Michoacán, Oaxaca, Quintana Roo. Tabasco, Yucatán).

- Five of the six apparel-producing regions I visited were founded by manufacturers who bad relocated their assembly operations from Mexico City.

- The average wage is calculated as total remuneration per worker. 
employment in apparel, employment in off-shore apparel assembly (assembly for foreign firms), and a breakdown of off-shore assembly between border and interior states. Between 1981 and 1988, the share of national apparel employment in off-shore assembly increased from 12.9 percent to 20.0 percent. Most job growth in off-shore assembly has taken place in interior Mexico, as firms that used to produce for the domestic market have shifted to assembly for foreign firms.

Table 2: Apparel Employment in Mexico, 1981-1989

\begin{tabular}{|c|c|c|c|c|c|c|}
\hline \multirow[b]{2}{*}{ Year } & \multirow{2}{*}{$\begin{array}{l}\text { Total } \\
\text { Employment }\end{array}$} & \multirow{2}{*}{$\begin{array}{l}\text { Off-Shore } \\
\text { Assembly }\end{array}$} & \multicolumn{2}{|c|}{ Border Assembly } & \multicolumn{2}{|c|}{ Interior Assembly } \\
\hline & & & Level & (\%) & Level & $(\%)$ \\
\hline 1981 & 143,986 & 18,059 & 14,278 & $(79.1)$ & 3,781 & $(20$. \\
\hline 1982 & $\ldots$ & 15,002 & 11,891 & (79.3) & 3,111 & $(20.7$ \\
\hline 1983 & -- & 16,212 & 12,885 & (79.5) & 3,327 & (20.5) \\
\hline 1984 & & 19,888 & 15,161 & $(76.2)$ & 4,727 & (23.8 \\
\hline 1985 & 146,809 & 21,473 & 15,089 & $(70.3)$ & 6,384 & $(29.7$ \\
\hline 1986 & - & 25,311 & 16,883 & $(66.7)$ & 8,428 & (33. \\
\hline 1987 & - & 30,273 & 19,399 & $(64.1)$ & 10,874 & (35. \\
\hline 1988 & 173,263 & 34,707 & 20,289 & $(58.5)$ & 14,418 & $(41$ \\
\hline 1989 & - & 42,400 & -. & & - & \\
\hline
\end{tabular}

- Total apparel employment includes the domestic and off-shore industries (figures for which are only available for census years). Source: Censo Industrial, various years; INEGI, La Industria Maquiladora de Exportación, various issues.

Figure 4 shows quarterly employment indices for domestic apparel production, off-shore apparel assembly, and all manufacturing (Bank of Mexico, unpublished data). Between 1987 and 1990, employment in the domestic apparel industry (firms that are not maquiladoras) increased by only 0.16 percent, while employment in off-shore apparel assembly increased by 39.5 percent. Figure 1 shows off-shore assembly exports have boomed since liberalization, increasing from US\$ 300.0 million in 1987 to US\$ 496.3 million in 1989. By contrast, domestic apparel exports rose from US\$ 52.7 million in 1987 to US\$ 68.3 million in 1989. 
Some observers attribute the tremendous export success of off-shore apparel assembly relative to the domestic apparel industry to trade barriers in the United States. Before NAFTA, the United States maintained quotas on Mexican apparel exports under the Multi-Fiber Arrangement. Mexico-U.S. trade agreements did give maquiladora exports first access to quotas, but quotas were binding in only a few product categories. Between 1988 and 1990, average quota utilization rates were over 60 percent in four product categories out of 61: overalls (112.9\%), pants (102.1\%), pajamas (88.6\%), and shirts and blouses $(80.9 \%) .^{10}$

NAFTA will further integrate Mexico into the U.S. economy by eliminating apparel quotas in the U.S. and tariffs on both sides of the border. Adjustment to trade liberalization provides a preview of the changes to come. For Mexico, NAFTA implies the continued conversion to apparel assembly and the continued relocation of production activities to the north. The further reduction of trade barriers is only likely to reinforce the emerging structure of production and bilateral trade flows, holding constant changes in other industries.

\section{Empirical Results}

The model predicts that under the closed economy regional wages are decreasing in transport costs to the industry center in Mexico City. Full estimation of the model is complicated by interactions between apparel and other activities and by the role of agriculture in labor supply. I estimate the regional wage structure as given by equation (19), which in general form is

$$
w / w_{c}=\delta_{l}
$$

where $w_{i}$ is the apparel wage in region $i, w_{c}$ is the apparel wage in the industry center, and $\delta_{i}$ is

so The pre-NAFTA bilateral trade agreement allowed Mexico to obtain quota increases for most goods on request (Convenio Bilateral Mexico-Estados Unidos 1988). 
unit transport costs between region $i$ and the industry center. In the open economy, this structure breaks down and regional relative wages are instead determined by access to foreign markets. I assume transport costs are an increasing function of distance, $d_{i}$. The regression equation is

$$
\log \left(w_{i} / w_{n}\right)=\beta_{\alpha}+\beta_{n} \log \left(d_{i}\right)+\mu_{i k}
$$

where s specifies the year and $\mu_{i k}$ is an error term whose structure I discuss below. Let $T$ be the unanticipated date of trade liberalization. Theory predicts

$$
\text { for } \begin{aligned}
t<T, & \beta_{t t}<0 \\
t>T, & \beta_{t t}=0
\end{aligned}
$$

The existence of free-trade zones along the Mexico-U.S. border in effect liberalized trade for the border before the rest of the country. This provides an additional testable hypothesis: given the access of border apparel producers to foreign industry centers, border apparel wages should be unrelated to distance from Mexico City. I test this hypothesis by allowing distance effects for border states to differ from those for interior states; that is, $I$ expect $\beta_{l}=0$ for border states.

Table 3 lists variable means and standard deviations. Wages are constructed from the Mexico Industrial Census. Mexico contains 32 states, including the Federal District. The wage variable I use, $w_{i n}$ is average annual remuneration per employee in the apparel industry of state $i$ in year $t^{\text {. }}$ A variety of factors generate regional wage differentials. To isolate regional wage differentials that are specific to the apparel industry, I divide $w_{i} / w_{N}$ by the ratio of the average manufacturing wage in state $i$ to the national average manufacturing wage. ${ }^{12}$ Complete state data are available for five years, $1970,1975,1980,1985$, and 1988, providing 155 observations ( 5

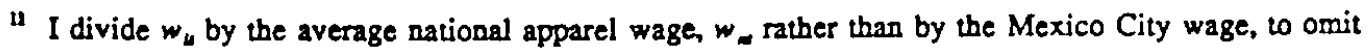
variation in the capital wage that is unrelated to the apparel industry.

12 Regression results with $\log \left(w_{/} / w_{\ldots}\right)$ as the dependent variable, rather than $\log \left(w_{1} / w_{2}\right)$ adjusted by the relative state manufacturing wage, are similar to those given below. 
years $\times 31$ states -- omitting the Federal District), of which four sets (1970-1985) correspond to the closed economy and one set (1988) corresponds to the open economy. To compensate for variation in transportation infrastructure actoss states, I measure distance as average hours required to travel by first-class passenger bus between the capital of state $i$ and Mexico City. ${ }^{13}$

\section{A. Econometric Issues}

I have observations on relative apparel wages across states and across time. To control for idiosyncratic components in the error term, I assume $\mu_{i}$ has the following form:

$$
\mu_{i}=\omega_{i}+v_{i}+\eta_{i}
$$

where $\omega_{i}$ is the effect for state $i, v_{1}$ is the effect for year $t$, and $\eta_{i,}$ is an i.d. random variable with mean zero and variance $\sigma^{2}$. If state and year effects are random, I can use OLS for estimation. Dwivedi and Srivastava (1978) show that in panel regression if the independent variables do not vary across groups of observations OLS is identical to GLS. In my case, the distance variables do not vary actoss time. This means in a regression of relative wages on log distance the OLS estimates of the $\beta$ 's are efficient even if the $\mu_{i}^{\prime}$ 's are correlated across states or years.

If state and year effects are fixed instead of random the solution is not so simple. Firstdifferencing the data eliminates the distance variable; using state dummy variables to control for fixed state effects introduces perfect multicollinearity. I first estimate the regression with and without year dummies. The distance variable, in addition to capturing transport costs, will pick up any other state effects that are correlated with distance to Mexico City. To determine what portion of fixed state effects are related to distance, I perform a second regression in which I

v Bus hours are from B. Box ed., South A merican Handbook 1990, New York: Prentice-Hall, (1990). 
replace distance with state dummies. The estimated state effects represent the mean effect of state characteristics on relative wages, controlling for the year. There are surely state characteristics besides distance that matter for wages, so replacing distance with state dummies will likely increase the explanatory power of the regression. To determine how much, I regress the estimated state dummies on distance. The variance in the estimated state effects that distance explains indicates the relative importance of distance among other state characteristics.

\section{B. Results}

Table 4 gives estimation results on regional relative apparel wages for 155 observations from 1970,1975, 1980,1985, and 1988. The (a) columns include year dummies; the (b) columns do not. I interact $\log$ distance with $B R D$, a dummy variable that takes a value of one if the state is a border state and with $y r 88$, a dummy variable that takes a value of one if the year is 1988 .

The results show strong support for the hypothesis that regional relative apparel wages decrease with distance from Mexico City. In all regressions $\log$ distance to Mexico City, $\log \left(d_{i}\right)$, is negative and significant at the .01 level. Moreover, the quantitative effect of distance is large. From the results in column (3b), a one standard deviation increase in log distance (0.966) reduces $\log$ state relative apparel wages by 0.339 , which is nearly half a standard deviation $(0.722)$. I do not find, however, that trade liberalization eliminates the distance effect. In two of four regressions, I reject the null hypothesis that $\log \left(d_{i}\right)$ is zero in 1988 at the .01 level. ${ }^{14}$

There is other evidence trade matters for wages. In all regressions I fail to reject the null

M This hypothesis is equivalent to the hypothesis that the sum of the coefficients on $\log (d)$ and $\log (d)^{*}$ yres is zero, which is the version I test. A weaker test is that the distance effect falls in 1988. In all regressions I fail to reject the hypothesis that the coefficient on $\log (d)$ is constant across years at the .05 level. 
hypothesis that $\log \left(d_{j}\right)$ is zero for border states at the .05 level. ${ }^{15}$ This is consistent with the hypothesis that border producers' access to foreign markets reduced the importance of distance from the domestic industry center in Mexico City. It may not seem surprising that wages on the Mexico-U.S. border are high relative to other regions. Recall, however, that my measure of relative wages controls for regional wage differentials at the state manufacturing level. Even controlling for overall wage differentials, then, apparel wages along the border are relatively high.

Table 5 shows results from regressing log relative wages on state and year dummies. Estimated state effects for four of the six border states are positive; three are significant at the .05 level. The only other positive state effect is that for the state of Mexico, which borders Mexico City. This is consistent with the findings from Table 4, that relative wages are high along the border. Comparing Table 5 with column (3b) in Table 4 shows that replacing distance variables with state dummies increases the adjusted $R^{2}$ from 349 to .793 . Distance appears to account for about two-fifths of the explained variance in regional relative apparel wages that is attributable to state characteristics. To verify this is the case, I regress the estimated state effects on the distance variables, again controlling for border states. The resulting regression is

$$
\omega_{1}^{\text {ale }}=\frac{-.0919-\left(.3111 * \log \left(d_{1}\right)+\right.}{(.2138)(.3269)}+.3939 * \log \left(d_{1}\right) * B R D \quad N=30, R^{2}=.414
$$

where standard errors are in parentheses and $\omega^{\alpha t}{ }_{i}$ is the estimated state effect for state $i$. Distance accounts for 41.4 percent of the variance in regional relative wages that is attributable to state characteristics. While other state-specific factors affect regional relative wages, distance is a relatively important among these characteristics. To ensure border states are not driving the

The hypothesis I test is that the sum of the coefficients on $\log (d)$ and $\log (d) * B R D$ is zero. 
results, I regress states effects for non-border states on distance:

$$
\omega^{\text {ale }}=\frac{-.0902-.3218 * \log \left(d_{1}\right) \quad N=24, R=.293}{(.2138)(.2299)}
$$

where $n b$ indicates non-border states. The coefficient estimates are consistent with those above, but the explained variance is lower.

I proceed to check the robustness of the results in Table 4. It is likely that improvements in roads, bridges, and transport equipment substantially reduced travel time between 1970 and 1988. This would affect the coefficient estimates if improvements in transportation were correlated with distance from Mexico City. To control for changes in the relationship between distance and transport costs, I allow distance effects to vary over time. Table 6 shows results where I interact $\log$ distance with dummy variables for border states and for year. The base category is interior states in 1970 . I find no evidence that distance effects vary over time. In all regressions I fail to reject the hypothesis that the distance variables interacted with year dummies are different from zero at the .05 level. Another possibility is that the distance effects are driven by the inclusion of border states in the regression. To verify this is not the case, I drop border states from the regression. Table 7 reports the results. Without border states, $\log$ distance from Mexico City remains negative and significant at the .01 level in all regressions.

The strength of the results is that even controlling for overall manufacturing wage differentials relative apparel wages are lower for states that are distant from the capital. While the results on border states are consistent with the hypothesis that trade liberalization has altered the closed-economy apparel wage structure, this does not imply that the open-economy wage structure will exhibit less disparity. Border states currently have relatively high wages and the continuing relocation of apparel jobs to the north - which is only likely to continue under 
NAFTA -- suggests that regional wage differentials will also be a feature of the open economy.

\section{Concluding Remarks}

This paper develops a model of regional subcontracting based on location-specific external economies. Localization economies arise endogenously from the provision of specialized inputs. Congestion costs due to agglomeration push low-skill activities into outlying regions. I apply the model to a study of the effects of trade liberalization on the Mexican apparel industry. Consistent with the model, apparel production in the closed economy was geographically concentrated. With the opening of the economy, the domestic apparel industry is converting to product assembly for foreign clients. Concurrently, producers are relocating their activities to the Mexico-U.S. border region. Estimation results on regional apparel wages are consistent with the existence of localization economies.

For a developing economy, trade liberalization involves a transition from verticallyintegrated manufacturing to a specialized role of subcontracting for developed-country firms. In apparel, and other labor-intensive industries, this transition implies the conversion to off-shore assembly and possibly profound changes in the spatial location of production. Sectoral-level analyses miss these changes by focusing on resource movements across industries while ignoring the organizational and locational changes that occur within industries. This has been the case in most if not all of the economy-wide models developed to study NAFTA (e.g., USITC 1992). The effects of NAFTA on the pattern of regional specialization in Mexico are likely to be at least as profound as those on the pattern of industrial specialization. 


\section{References}

Convenio Bilateral Mexico-Estados Unidos 1988. Mexico: Secretaria de Comercio y Fomento Industrial.

Dwivedi, T.D. and V.K. Srivastava. 1978. "Optimality of Least Squares in the Seemingly Unrelated Regression Equation Model." Journal of Econometrics 7: 391-395.

Fujita, M. 1988. "Monopolistic Competition and Urban Systems." European Economic Review 37: 308-15.

Grunwald, J. and K. Flamm. 1985. The Global Factory: Foreign A ssembly in International Trade. Washington, DC: The Brookings Institution.

Hanson, G. 1994. "Increasing Returns and the Regional Structure of Wages." Mimeo, University of Texas.

Helpman, E. and P. Krugman. 1985. Market Structure and Foreign Trade. Cambridge, MA: MTT Press.

Instituto Nacional de Estadística, Geographra e Informática (INEGI). Censo Comercial, 1981, XI Censo Industrial, 1981. Mexico City: INEGI.

INEGI. 1989a Estadisticas de la Industria Maquiladora de Exportación, 1978-1988, Aguascalientes: INEGI, 1989.

INEGI. 1989b. Resultados Oportunos. Aguascalientes: INEGI.

King, T. 1970. Mexico: Industrialization and Trade Policies Since 1940. London: Oxford University Press.

Krugman, P. 1991. "Increasing Returns and Economic Geography." Journal of Political Economy 99: 483-499.

Krugman, P. and A. Venables. 1993. "Integration, Specialization, and Adjustment." NBER Working Paper No. 4559.

Lichtenberg, R. 1960. One-Tenth of a Nation. Cambridge, MA: Harvard University Press.

Markusen, J.R. and T.F. Rutherford. 1993. "Discrete Plant-Location Decisions in an Applied General-Equilibrium Model of Trade Liberalization." NBER Working Paper No. 4513.

Michaely, M., D. Papageorgious, and A.M. Choksi. 1991. Liberalizing Foreign Trade: Lessons of Experience in the Developing World, Vol. 7. Cambridge, MA: Basil Blackwell. 
Rivera-Batiz, F.L. 1988. "Increasing Returns, Monopolistic Competition, and Agglomeration Economies in Consumption and Production." Regional Science and Urban Economics 18: 12553.

Secretarfa de Programación y Presupuesto (SPP). IX Censo Industrial, 1971, X Censo Industrial, 1976. Mexico City: SPP.

United States International Trade Commission. 1992. Economy-Wide Implications of a FTA with Mexico and a NAFTA with Canado and Mexico. USITC Publication 2508.

Waldinger, R.D. 1986. Through the Eye of the Needle: Immigrants and Enterprise in New York's A pparel Trades. New York: NYU Press.

White, H. 1980. "A Heteroskedasticity-Consistent Covariance Matrix Estimator and a Direct Test for Heteroskedasticity." Econometrice 48: 817-838. 
</ref_section> 


\section{Appendix A: International Trade with Mobile Labor}

Suppose now labor is mobile between countries. Since my focus is the long-run trade equilibrium, I ignore migration costs and assume labor mobility is perfect. Home labor in Foreign, then, earns the same wage as Foreign labor. Let $L^{f}$ be the number of workers that migrate from Home to Foreign. In addition to the profit-maximization conditions in (30)-(33), we have the condition that real wages are equalized between Home and Foreign. Following (22)

$$
\text { (a1) } \frac{w\left(L-L^{n}\right)}{P_{x} X}=\frac{w^{*}\left(L^{*}+L^{n}\right)}{P^{*} x^{*}}
$$

Let $p=X^{*} \mid X$, where I assume $p>1$. If $Z$ production occurs in both regions, it still holds that $w^{\circ} / w=1 / \gamma$. Following (24), real-wage equalization in Home and Foreign implies $P_{x}^{*} / P_{s}=$ $(1 / \gamma)^{\text {s/a }}$. Putting these results together with (a1)

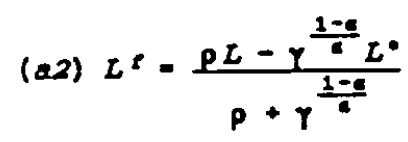

The condition for positive migration is $\rho>\gamma^{(\text {s-ava }}$, which requires Foreign have sufficient land relative to Home that migration from Home to Foreign does not violate the land-rent differential imposed by transport costs. From (a2) and the conditions imposed by profit maximization,

$$
\text { (a3) } N^{*}=\frac{\rho L\left(1+r^{\frac{1}{a}}\right)+L^{*}\left(p+r^{\frac{1}{a}}\right)}{a\left(p+r^{\frac{1}{a}}\right)} \theta(1-\sigma)
$$

From (a3) it is straightforward to derive total employment in services, total employment in $Z$, and the remaining relative prices. The basic results do not change from the trading equilibrium with immobile labor. In the small country (Home), trade again causes wage compression and spatial decentralization; in the trading equilibrium, we again have the formation of a regional production network, with the industry center in the large country and input production in the small country. 


\section{Appendix B: Data from Firm-level Interviews}

The data are from 95 firm-level interviews conducted with apparel manufacturers and subcontractors in seven Mexican cities between September, 1990, and May, 1991. Interviews were arranged through five organizations: the National Apparel Industry Chamber (78), Dynamic Consultants to Micro-Enterprises (6) the September 19th Apparel Workers Union (5), the National Autonomous University of Mexico (2), and the Authentic Labor Front (2). Interviews followed a general questionnaire and ranged from one to four hours. The questionnaire and interview transcripts are available on request. The following lists interviews by location and activity:

Mexico City (52)

Apparel Industry Chamber

Fashion and Design Center

Men's Outerwear

General Subcontracting

Other

Monterrey. Nuevo León (13)

Women's Outerwear

Pants

Shirts

Othe:

Aquascalientes, Ags (9)

Children's Outerwear

Linens

Other.

Nezahuacoyoth. Mex (2)

Subcontracting
Number

5

\section{6}

2

2

3

Tehuacán. Puebla (7)

\section{Pants}

Shirts

Unions

Women's Outerwear

Knitwear

Retailers/Traders

Number

Guadalajara Jalisce(10)

Women's Outerwear

6

Other

2

2

Almoloya del Ría. Mex (2)

Subcontracting

2 
Table 3: Variable Means and Standard Deviations

\begin{tabular}{|c|c|c|c|}
\hline & Mean & Std. Dev. & Obs. No. \\
\hline Distance (hrs) & 14.25 & 14.12 & 31 \\
\hline \multicolumn{4}{|c|}{ State Apparel Wage/ National Apparel Wage } \\
\hline 1970 & 0.516 & 0.281 & 31 \\
\hline 1975 & 0.602 & 0.435 & 31 \\
\hline 1980 & 0.566 & 0.317 & 31 \\
\hline 1985 & 0.662 & 0.383 & 31 \\
\hline 1988 & 0.688 & 0.386 & 31 \\
\hline $1970-1988$ & 0.607 & 0.365 & 155 \\
\hline \multicolumn{4}{|c|}{$\begin{array}{l}\text { (State Apparel Wage/National Apparel Wage)/ } \\
\text { (State Manufacturing Wage/National Manufacturing Wage) }\end{array}$} \\
\hline 1970 & 0.723 & 0.232 & 31 \\
\hline 1975 & 0.764 & 0.409 & 31 \\
\hline 1980 & 0.681 & 0.424 & 31 \\
\hline$i \neq 35$ & 0.861 & 0.643 & 31 \\
\hline 1988 & 0.923 & 0.572 & 31 \\
\hline $1970-1988$ & 0.790 & 0.490 & 155 \\
\hline
\end{tabular}

- Values are for all states except the Federal District, the federal entity that contains Mexico City. 
Table 4: Regression of State Relative Wages on Distance from Mexico City (heteroskedasticity-consistent standard errors in parentheses)

\begin{tabular}{|c|c|c|c|c|c|c|}
\hline Variable & (1a) & (1b) & $(2 a)$ & $(2 b)$ & (3a) & (3b) \\
\hline constant & $\begin{array}{l}-0.395 \\
(0.125)\end{array}$ & $\begin{array}{l}-0.508 \\
(0.151)\end{array}$ & $\begin{array}{l}-0.395 \\
(0.123)\end{array}$ & $\begin{array}{l}-0.453 \\
(0.152)\end{array}$ & $\begin{array}{l}-0.395 \\
(0.122)\end{array}$ & $\begin{array}{l}-0.442 \\
(0.156)\end{array}$ \\
\hline $\log \left(d_{i}\right)$ & $\begin{array}{r}-0.318^{\infty} \\
(0.068) \\
\end{array}$ & $\begin{array}{r}-0.318^{\infty} \\
(0.067) \\
\end{array}$ & $\begin{array}{l}-0.336^{\circ} \\
(0.065) \\
\end{array}$ & $\begin{array}{l}-0.343^{\circ} \\
(0.067) \\
\end{array}$ & $\begin{array}{l}-0.339^{* 0} \\
(0.066)\end{array}$ & $\begin{array}{l}-0.351^{\oplus \bullet} \\
(0.071)\end{array}$ \\
\hline $\log \left(d_{i}\right)^{*} B R D$ & $\begin{array}{l}0.388^{\circ} \\
(0.038)\end{array}$ & $\begin{array}{c}0.388^{\infty} \\
(0.037) \\
\end{array}$ & $\begin{array}{c}0.388^{\star *} \\
(0.037) \\
\end{array}$ & $\begin{array}{c}0.388^{\circ \bullet} \\
(0.037)\end{array}$ & $\begin{array}{c}0.399^{* *} \\
(0.038)\end{array}$ & $\begin{array}{c}0.402^{\infty} \\
(0.040)\end{array}$ \\
\hline $\log \left(d_{i}\right)^{*} y r 88$ & & & $\begin{array}{c}0.088 \\
(0.054)\end{array}$ & $\begin{array}{c}0.124 \\
(0.136)\end{array}$ & $\begin{array}{c}0.106 \\
(0.076)\end{array}$ & $\begin{array}{c}0.166 \\
(0.178)\end{array}$ \\
\hline $\log \left(d_{i}\right) * y r 88 * B R D$ & & & & & $\begin{array}{l}-0.056 \\
(0.084)\end{array}$ & $\begin{array}{l}-0.068 \\
(0.098)\end{array}$ \\
\hline Adj. $R^{2}$ & 0.349 & 0.351 & 0.359 & 0.351 & 0.356 & 0.349 \\
\hline Obs. No. & 155 & 155 & 155 & 155 & 155 & 155 \\
\hline $\begin{array}{l}\mathrm{F}[\mathrm{dof}, \mathrm{dof}] \text { on } \\
\mathrm{H}_{0}: \log \left(\mathrm{d}_{\mathrm{i}}\right)= \\
\quad-\log \left(\mathrm{d}_{\mathrm{i}}\right)^{*} \mathrm{yr} 88\end{array}$ & & & $\begin{array}{c}8.63^{\circ} \\
{[1,151]}\end{array}$ & $\begin{array}{c}2.60 \\
{[1,147]}\end{array}$ & $\begin{array}{c}5.95^{\star \bullet} \\
{[1,150]}\end{array}$ & $\begin{array}{c}1.28 \\
{[1,146]}\end{array}$ \\
\hline $\begin{array}{c}\mathrm{F}[\text { dnf dof }] \text { on } \\
\mathrm{H}_{0}: \log \left(\mathrm{d}_{1}\right)= \\
-\log \left(\mathrm{d}_{1}\right) * B R D\end{array}$ & $\begin{array}{c}2.92 \\
{[1,152]}\end{array}$ & $\begin{array}{c}3.10 \\
{[1,148]}\end{array}$ & $\begin{array}{c}1.76 \\
{[1,151]}\end{array}$ & $\begin{array}{c}1.06 \\
{[1,147]}\end{array}$ & $\begin{array}{c}2.29 \\
{[1,150]}\end{array}$ & $\begin{array}{c}1.45 \\
{[1,146]}\end{array}$ \\
\hline $\begin{array}{l}\mathrm{F}[\text { dof dof }] \text { on } \mathrm{H}_{0}: \\
\text { year dummies }=0\end{array}$ & & $\begin{array}{c}1.27 \\
{[3,148]}\end{array}$ & & $\begin{array}{c}0.54 \\
{[4,147]} \\
\end{array}$ & & $\begin{array}{c}0.57 \\
{[4,146]} \\
\end{array}$ \\
\hline year dummies & no & yes & no & yes & no & yes \\
\hline
\end{tabular}

* (**) Indicates significance at the $.05(.01)$ level. BRD is a dummy variable that indicates border states. yr88 is a dummy variable that indicates the year is 1988 . 
Table 5: Fixed-Effects Estimation

\begin{tabular}{|c|c|c|c|c|c|}
\hline Variable & Coeff. & St. Err. & Variable & Coeff. & St. EnT. \\
\hline constant & -0.455 & 0.071 & Oaxaca & $-1.651^{\circ *}$ & 0.116 \\
\hline Baja California & $0.273^{\circ}$ & 0.091 & Puebla & $-0.206^{\circ}$ & 0.067 \\
\hline Baja Calif. Sur & $-0.434^{\infty}$ & 0.209 & Quintana Roo & $-0.916^{\circ}$ & 0.203 \\
\hline Chihuahua $^{B}$ & $0.281^{\circ \infty}$ & 0.064 & Querétero & -0.034 & 0.176 \\
\hline Chiapas & $-2.096^{\circ}$ & 0.133 & Sinaloa & $-0.798^{\infty}$ & 0.068 \\
\hline Campeche & $-1.483^{\circ}$ & 0.238 & San Lurs Potosi & $-0.281^{\circ}$ & 0.068 \\
\hline Coahuila $^{{ }^{B}}$ & -0.006 & 0.092 & Sonora & 0.176 & 0.105 \\
\hline Colima & $-1.856^{\circ}$ & 0.233 & Tabasco & $-1.394^{\circ \bullet}$ & 0.094 \\
\hline Durango & -0.152 & 0.108 & Tamaulipas $^{\mathbf{B}}$ & -0.013 & 0.062 \\
\hline Guerrero & $-0.386^{\circ}$ & 0.140 & Tlaxcala & $-0.317^{\infty}$ & 0.116 \\
\hline Guanajuato & $-0.262^{\circ}$ & 0.079 & Veractuz & $-1.312^{\infty}$ & 0.079 \\
\hline Hidalgo & $-0.382^{\circ}$ & 0.095 & Yucatán & $-0.431^{\infty}$ & 0.100 \\
\hline Jalisco & -0.044 & 0.066 & Zacatecas & $-0.817^{\circ}$ & 0.236 \\
\hline Michoacán & $-0.845^{\infty}$ & 0.095 & yr75 & 0.110 & 0.076 \\
\hline México & $0.192^{\circ}$ & 0.088 & yr80 & 0.011 & 0.067 \\
\hline Mo.rins & -0.466 & 0.343 & yr85 & $0.185^{\circ}$ & 0.067 \\
\hline Nayartt & $-1.060^{\circ}$ & 0.133 & yr88 & $0.259^{\circ \bullet}$ & 0.060 \\
\hline Nuevo León & $0.259^{\circ \circ}$ & 0.091 & Adj. $R^{2}=0.793$ & \multicolumn{2}{|c|}{ Obs. No. $=155$} \\
\hline
\end{tabular}

**) Indicates significance at the $.05(.01)$ level. Indicates border state. (Omitted state is Aguascalientes; omitted year is 1970.) 
Table 6: Regression Results with Time-Varying Coefficients (heteroskedasticity-consistent standard errors in parentheses)

\begin{tabular}{|c|c|c|c|c|}
\hline Variable & (1a) & (1b) & $(2 a)$ & $(2 b)$ \\
\hline $\log \left(d_{i}\right)$ & $\begin{array}{l}-0.354^{\circ} \\
(0.070) \\
\end{array}$ & $\begin{array}{l}-0.272^{\circ} \\
(0.097)\end{array}$ & $\begin{array}{l}-0.349^{\circ} \\
(0.176) \\
\end{array}$ & $\begin{array}{l}-0.250^{\circ} \\
(0.114) \\
\end{array}$ \\
\hline $\log \left(d_{i}\right)^{*} B R D$ & $\begin{array}{c}0.388^{\circ} \\
(0.037) \\
\end{array}$ & $\begin{array}{l}0.388^{\circ} \\
(0.036) \\
\end{array}$ & $\begin{array}{l}0.374^{\circ \bullet} \\
(0.061) \\
\end{array}$ & $\begin{array}{r}0.352^{\circ} \\
(0.064) \\
\end{array}$ \\
\hline $\log \left(d_{1}\right)^{*} y r 88$ & $\begin{array}{c}0.106 \\
(0.061) \\
\end{array}$ & $\begin{array}{c}0.053 \\
(0.155) \\
\end{array}$ & $\begin{array}{c}0.116 \\
(0.087) \\
\end{array}$ & $\begin{array}{c}0.065 \\
(0.199) \\
\end{array}$ \\
\hline $\log \left(d_{i}\right)^{*} y 185$ & $\begin{array}{c}0.045 \\
(0.063) \\
\end{array}$ & $\begin{array}{l}-0.165 \\
(0.145) \\
\end{array}$ & $\begin{array}{c}0.043 \\
(0.091) \\
\end{array}$ & $\begin{array}{l}-0.202 \\
(0.197) \\
\end{array}$ \\
\hline $\log \left(d_{1}\right)^{*} y 180$ & $\begin{array}{c}0.009 \\
(0.064) \\
\end{array}$ & $\begin{array}{r}0.032 \\
(0.134) \\
\end{array}$ & $\begin{array}{l}-0.006 \\
(0.093) \\
\end{array}$ & $\begin{array}{r}0.006 \\
(0.183) \\
\end{array}$ \\
\hline $\log \left(\mathrm{d}_{i}\right)^{*} \mathrm{yr} 75$ & $\begin{array}{c}0.019 \\
(0.051) \\
\end{array}$ & $\begin{array}{l}-0.150 \\
(0.133) \\
\end{array}$ & $\begin{array}{c}0.003 \\
(0.073) \\
\end{array}$ & $\begin{array}{l}-0.208 \\
(0.172) \\
\end{array}$ \\
\hline $\begin{array}{l}\log \left(d_{1}\right) * B R D \\
* y r 88\end{array}$ & & & $\begin{array}{l}-0.031 \\
(0.097) \\
\end{array}$ & $\begin{array}{l}-0.019 \\
(0.110) \\
\end{array}$ \\
\hline $\begin{array}{l}\log \left(d_{1}\right) * B R D \\
* y r 85\end{array}$ & & & $\begin{array}{c}0.006 \\
(0.096) \\
\end{array}$ & $\begin{array}{c}0.061 \\
(0.111) \\
\end{array}$ \\
\hline $\begin{array}{l}\log \left(d_{i}\right) * B R D \\
* y 180\end{array}$ & & & $\begin{array}{c}0.046 \\
(0.098) \\
\end{array}$ & $\begin{array}{c}0.043 \\
(0.107) \\
\end{array}$ \\
\hline $\begin{array}{l}\log \left(d_{1}\right) * B R D \\
* y r 75\end{array}$ & & & $\begin{array}{c}0.048 \\
(0.081) \\
\end{array}$ & $\begin{array}{r}0.095 \\
(0.092) \\
\end{array}$ \\
\hline Adj. $R^{2}$ & 0.349 & 0.349 & 0.333 & 0.335 \\
\hline Obs. No. & 155 & 155 & 155 & 155 \\
\hline $\begin{array}{l}F[\text { dof,dof }] \text { on } H_{0}: \\
\log \left(d_{i}\right)=-\log \left(d_{1}\right)^{*} y r 88\end{array}$ & $\begin{array}{c}8.64^{\infty} \\
{[1,148]} \\
\end{array}$ & $\begin{array}{c}2.60 \\
{[1,144]} \\
\end{array}$ & $\begin{array}{c}5.96^{\circ} \\
{[1,144]} \\
\end{array}$ & $\begin{array}{c}1.28 \\
{[1,140]} \\
\end{array}$ \\
\hline $\begin{array}{l}\mathrm{F}\left[\text { dof,dof] on } \mathrm{H}_{0}:\right. \\
\log \left(\mathrm{d}_{1}\right)=-\log \left(\mathrm{d}_{2}\right)^{*} \mathrm{BRD}\end{array}$ & $\begin{array}{c}0.45 \\
{[1,148]} \\
\end{array}$ & $\begin{array}{c}1.76 \\
{[1,144]} \\
\end{array}$ & $\begin{array}{c}0.29 \\
{[1,144]} \\
\end{array}$ & $\begin{array}{c}1.87 \\
{[1,140]} \\
\end{array}$ \\
\hline $\begin{array}{l}\mathrm{F} \text { [dof,dof] on } \mathrm{H}_{0}: \text { yr } \\
\text { interaction terms }=0\end{array}$ & $\begin{array}{c}0.18 \\
{[3,148]} \\
\end{array}$ & $\begin{array}{c}1.02 \\
{[3,144]}\end{array}$ & $\begin{array}{c}0.54 \\
{[6,144]} \\
\end{array}$ & $\begin{array}{r}0.85 \\
{[6,140]} \\
\end{array}$ \\
\hline year dummies & no & yes & no & yes \\
\hline
\end{tabular}

$\mathrm{yrXX}$ is a dummy variable that indicates the year is 19XX; other definitions as in Table 4. 
Table 7: Regression Results Excluding Border States (heteroskedasticity-consistent standard errors in parentheses)

\begin{tabular}{|c|c|c|c|c|}
\hline Variable & (1a) & (1b) & $(2 a)$ & $(2 b)$ \\
\hline constant & $\begin{array}{l}-0.391 \\
(0.069)\end{array}$ & $\begin{array}{l}-0.498 \\
(0.165)\end{array}$ & $\begin{array}{l}-0.391 \\
(0.073)\end{array}$ & $\begin{array}{l}-0.638 \\
(0.235)\end{array}$ \\
\hline $\log \left(d_{i}\right)$ & $\begin{array}{l}-0.319^{\circ} \\
(0.070)\end{array}$ & $\begin{array}{l}-0.319^{\circ} \\
(0.068)\end{array}$ & $\begin{array}{l}-0.351^{\infty} \\
(0.078)\end{array}$ & $\begin{array}{l}-0.250^{\circ} \\
(0.116)\end{array}$ \\
\hline $\log \left(d_{1}\right)^{*} y r 88$ & & & $\begin{array}{c}0.116 \\
(0.087) \\
\end{array}$ & $\begin{array}{c}0.063 \\
(0.204)\end{array}$ \\
\hline $\log \left(d_{i}\right)^{*}$ yr 85 & & & $\begin{array}{c}0.043 \\
(0.091)\end{array}$ & $\begin{array}{l}-0.207 \\
(0.202) \\
\end{array}$ \\
\hline $\log \left(d_{1}\right)^{*} y r 80$ & & & $\begin{array}{l}-0.006 \\
(0.093)\end{array}$ & $\begin{array}{c}0.007 \\
(0.186) \\
\end{array}$ \\
\hline $\log \left(d_{1}\right)^{*} y r 75$ & & & $\begin{array}{c}0.004 \\
(0.073) \\
\end{array}$ & $\begin{array}{l}-0.209 \\
(0.177) \\
\end{array}$ \\
\hline Adj. $\mathrm{R}^{2}$ & 0.169 & 0.166 & 0.164 & 0.162 \\
\hline Obs. No. & 125 & 125 & 125 & 125 \\
\hline $\begin{array}{l}F[\text { dof,dof }] \text { on } H_{0}: \\
\log \left(d_{1}\right)=-\log \left(d_{i}\right)^{*} y r 88\end{array}$ & & & $\begin{array}{r}5.86^{\circ} \\
{[1,119]} \\
\end{array}$ & $\begin{array}{c}1.24 \\
{[1,115]}\end{array}$ \\
\hline $\begin{array}{l}\text { F[dof,dof] on } \mathrm{H}_{0}: \text { yr } \\
\text { interaction terms }=0\end{array}$ & & & $\begin{array}{c}0.59 \\
{[4,119]} \\
\end{array}$ & $\begin{array}{c}0.76 \\
{[4,115]} \\
\end{array}$ \\
\hline year dummies & no & yes & no & yes \\
\hline
\end{tabular}

Note. Tefinitions from Tables 4 and 6 apply. 


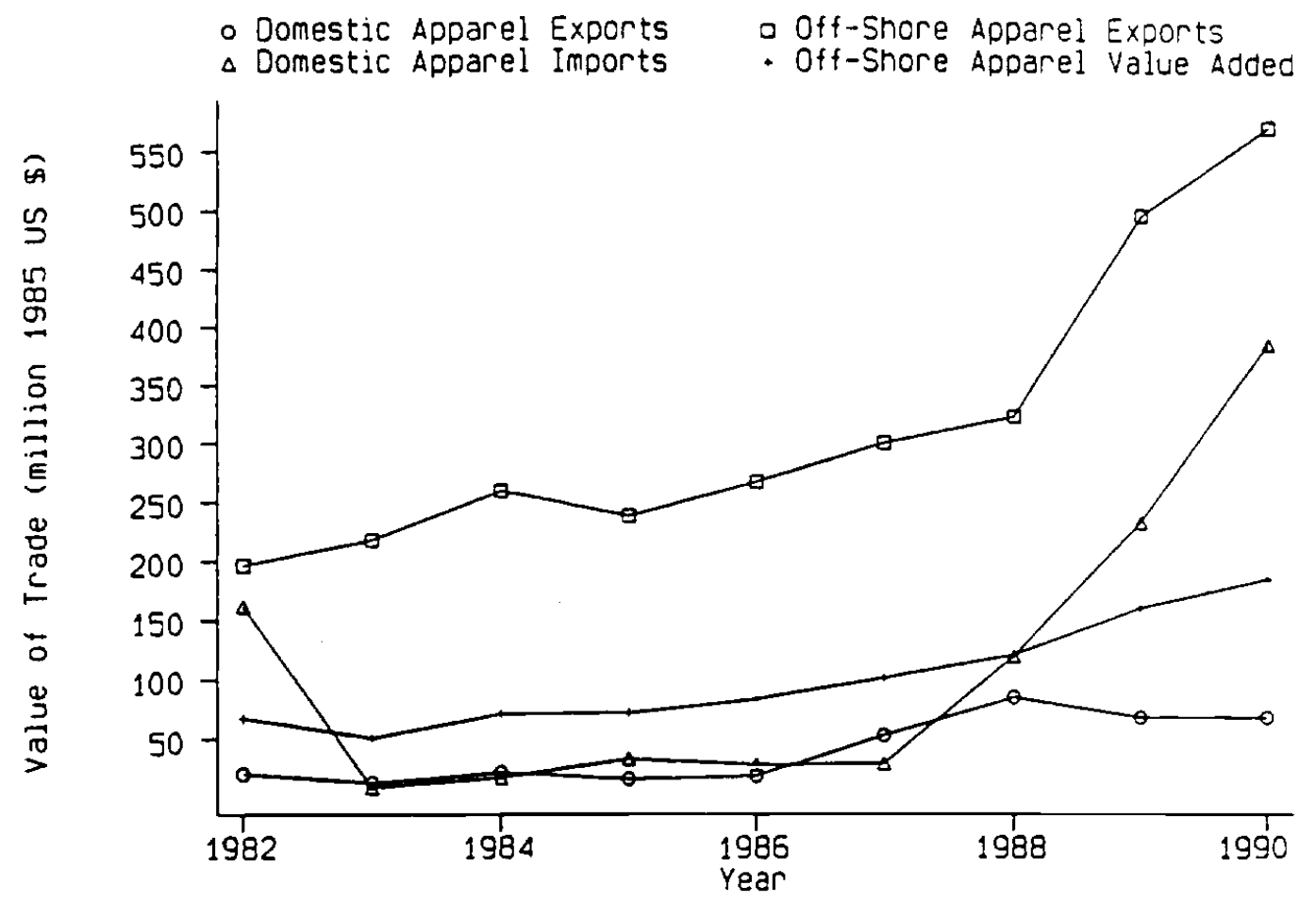

Figure 1: Mexico Foreign Apparel Trade, 1982-1990 


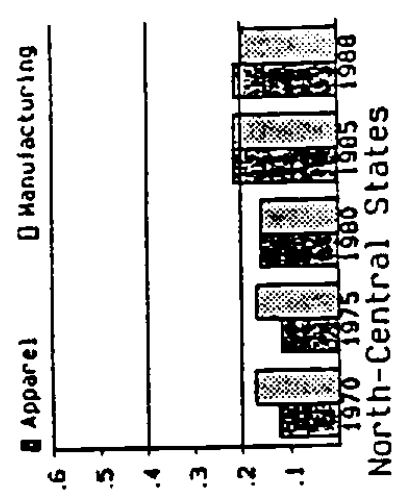

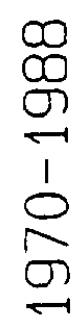
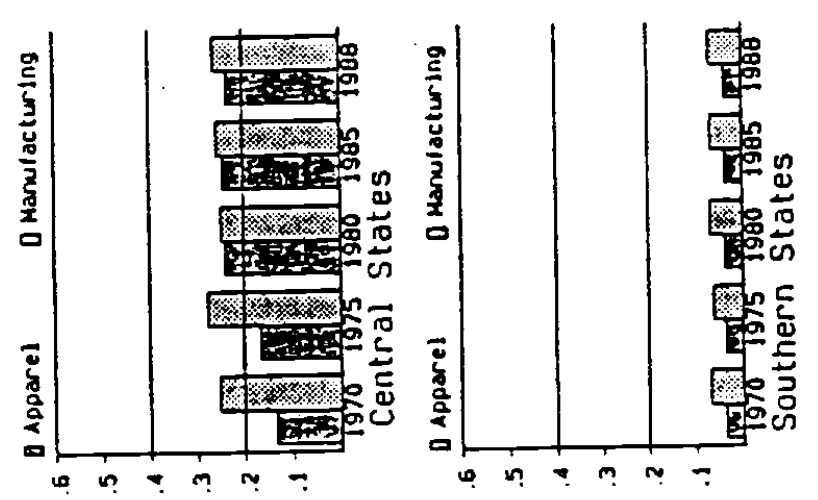

()

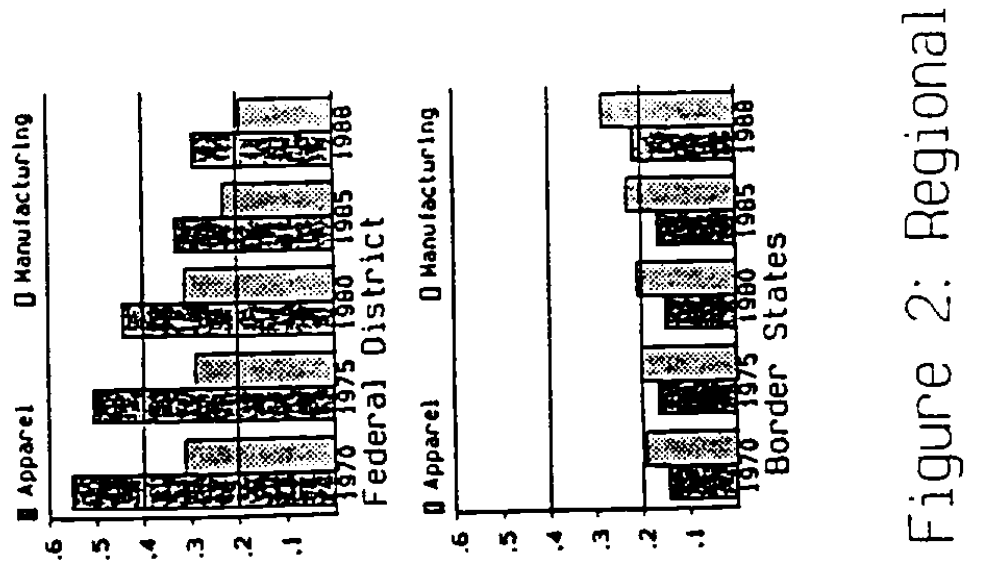

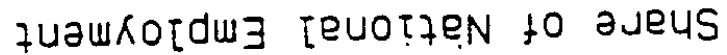




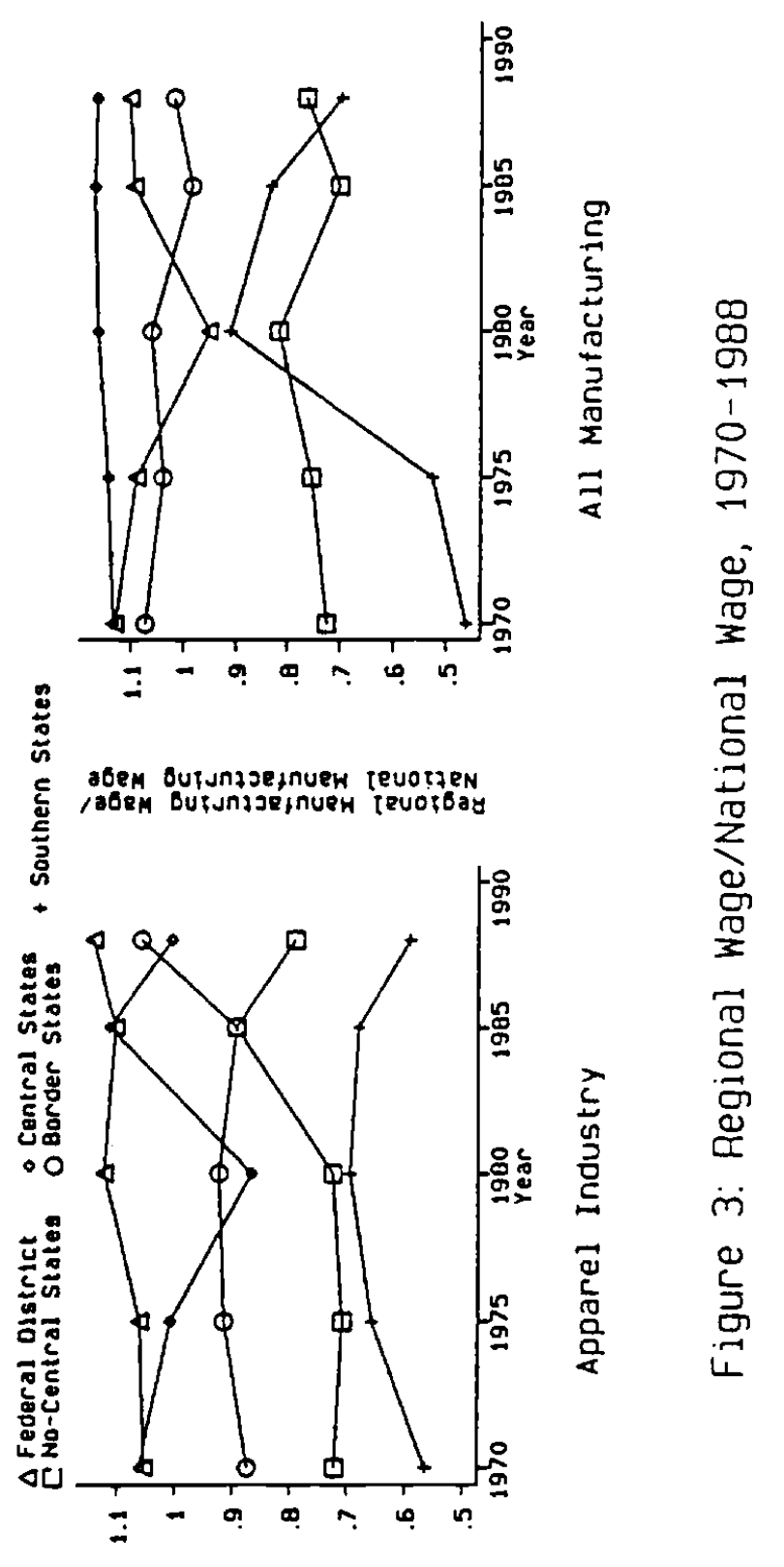

abem lajeddy tevotaen labem tajeddr ievojóay 


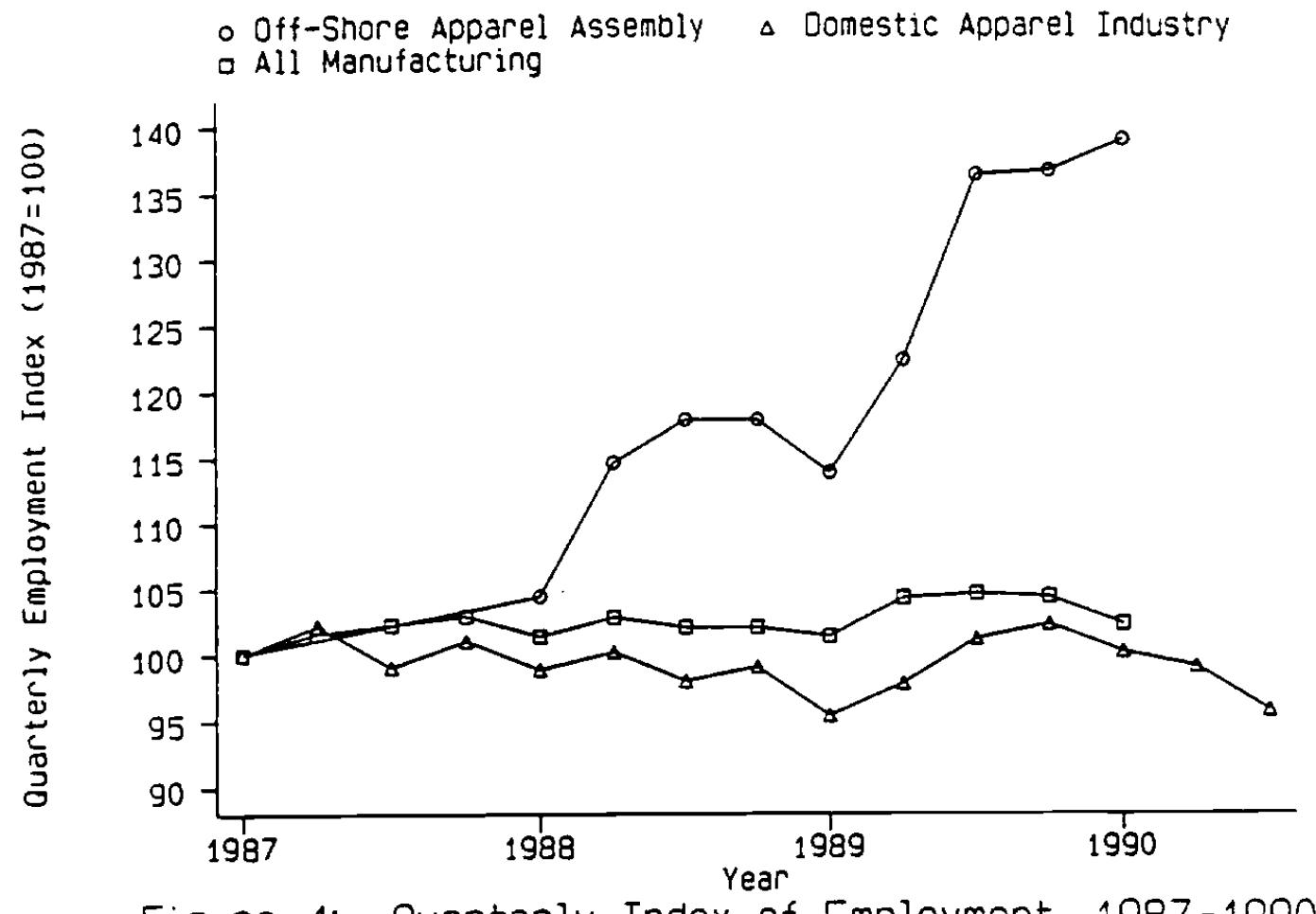

Figure 4: Quarterly Index of Employment, 1987-1990 